\title{
Emotional Intelligence of Secondary School Teachers and Socio- Demographic Factors Nexus: An Empirical Investigation in the District Vehari
}

\section{Hafsah Batool Lahore}

Lecturer of Economics, Department of Economics, Lahore College for Women University Lahore (LCWU) Pakistan batooleconomist@gmail.com

Nabeela Nazly

Deputy Controller of Examination ,Lahore College for Women University Lahore (LCWU) Pakistan nabeela.nazly@lcwu.edu.pk

\begin{abstract}
The study was aimed to investigate the emotional intelligence of secondary school teachers. The descriptive research design was used in this study. Further, Survey method was applied to collect data using questionnaire. It was quantitative analysis base study. Secondary school teachers i.e. 890 of district Vehari were the population of the study out of whom 267 teachers were selected as sample. The sample was selected using cluster random sampling. Daniel Goleman (1995) was developed a structured questionnaire that is used in this study. It was consisted of 50 statements under five factors of EI i.e. self-awareness, managing oneself, managing emotions, empathy, and social skill. Th,e piloting of the instrument was also done. Cronbach Alpha value was found to be 0.74 . The data were collected by the researcher herself and with the help of friends. The response rate was $93.6 \%$. SPSS was used for database development and analysis. No significant difference was found between age, gender and experience for five factors of emotional intelligence. It was recommended that there should be a training program to develop EI in teachers.
\end{abstract}

Keywords:

Emotional management, emotional intelligence, self-consciousness, self-motivation, self-awareness, and relationship management.

Article Received: 18 October 2020, Revised: 3 November 2020, Accepted: 24 December 2020

\section{INTRODUCTION}

Emotions give the way to present how we behave and feel in a situation. Emotional intelligence is the phenomenon under study during the last two decades. Goleman (1995) in his book stated that emotional intelligence (EI) matters twice than IQ in defining the success of an individual. The emotional intelligence base perception is that individuals should have a clear awareness of their feelings and can deal the emotions in a real way. Education plays the main part in increasing emotional intelligence (Goleman, 2006).

Emotional intelligence is the ability to perceive emotions, to access and generate emotions so as to assist thought, to understand emotions and emotional knowledge, and to reflectively regulate emotions so as to promote emotional and intellectual growth (Goleman, 2006; Schutte et al.,
1998). Goleman (1998) defined EI as selfawareness of a teacher that develop the ability not only to identify feelings but also manage emotions to their students in an appropriate manner. Emotional intelligence (EI) is the capability to identify one's own and other emotions, to differentiate between different emotional states and tag them correctly, and to use emotional information to lead thinking and performance (Carthy and Jameson, 2016).

The psychological development also of pupils is made easier by the role of educators. The teacher can change and mold the main thing, i.e. the young male and female students, to make significant characters during the most important time of their development. They have to look beyond intellectual competence, professional qualifications and educational qualifications to 
become efficient educators. The consequences of the teachers ' emotional skill level can be expressed in the form of student performance (Brackett and Katulak, 2006). A teacher's failure to develop a school atmosphere that promotes fast pace of teaching can prevent the performance of the student while the quality of communication that has been developed with his / her students explains teacher's performance.

Based on this history, the scientists proposed that instructors should be trained to develop their emotional skills in particular (Hawkey,2006). The study of history has proved that good teachers play a critical role in the development of society. It is important that teacher must possess dynamic skills, traits, energetic personality, positive behaviour and attitude in order to have an impact on the motivation of student for learning perspective (Lenka and Kant, 2012). He wants to outshine in their occupation but the ability to make development and handle emotional intelligence is very important. The study of today classrooms has suggested that teachers are not capable to regulate emotions and feelings of students and make appropriate reactions.

They are not able to handle small problems and get upset with them. The important reason behind this issue is that teachers are an overburden. They not only to have delivered lectures to students but also school management make them responsible for some managerial tasks. Moreover, their own problems also have a negative impact on their personalities. All these factors play a very important role in affecting the feelings and emotions of teachers. Therefore, teachers cannot perform efficiently and effectively because of not having the ability to understand their own feelings and students' feelings.

In addition, emotionally intellectual teachers can also acknowledge how their words and behavior can influence their students ' behavior and emotions. Grant (1993) regarded a teacher's behavior as a way to encourage learners to take part in multiple classes. The role of emotional regulation by a teacher as a means to guide student achievement in the context of Taiwan has been further endorsed by, She and Fisher in 2002. The ability of educators to comprehend the material of the classroom and to perform well in tests or exams is measurable. A friendly classroom atmosphere that teachers maintained supported the amount of cognitive development attained by learners.

Charles Darwin, who thought them to play an essential part in sustaining lives, as well as altering one's self, to adapt better to altering external situations, could be attributable to the original job done within the field of emotional intelligence in human existence (Zeidner, Matthews \& Roberts, 2009).. In addition to Thorndike's original job on the connections between feelings and intelligence, it is worth mentioning who has conceptualized the phenomenon as social intelligence (Thorndike).

The study focuses on the three aspects of wellbeing, emotionality and socialization as well as the fourth component of self-confidence. Although the word trait EI is used, an individual's degree of emotions intelligence does not represent the existence of an inherent personality trait, rather, EI shows an individual's ability to effectively handle his or her personal and others ' feelings. In the present research, the characteristic EI is placed to demonstrate an individual's emotional competence, which directs his behavior to himself and others in the environment. Law et al. (2004, p. 483) also endorsed this concept and stated that "EI conceptually differs from personality," thus establishing a distinction between personality and EI as a feature based on competence. Personality can be regarded as the ability to manage personal and others ' feelings, even though it consists of characteristics, as a trait.

Many researchers also tried to measure the amount of EI of a person by TEIQue. It sees emotional intelligence as a measuring tool of EI a type of personality trait. Freudenthaler et al. 
(2008) used it to validate the use of TEIQ as an opportunity to identify the EI level in the five domains, and to explore the relationship with an individual's life satisfaction. Four variables in EI included in the questionnaire were also discovered to be substantially linked to an individual's perception of his / her life. TEIQue includes the building blocks of well-being, emotionality and sociability (as described in Figure 2). But study has not included the constructs of self-control and cultural EI. In addition, as part of this inquiry, overall EI was also evaluated. The model of Daniel Goleman (1998) has highlighted in particular the skills and skills that lead effectively is consists of contain five elements. This research focuses on wellbeing, self-confidence, emotion, sociability and motivation, in accordance with Daniel Goleman's model. Also, a central region of study was the relationship between emotional intelligence and leaders ' performance. The capacity of a leader to communicate with, inspire, and encourage his supporters to share their vision of the future, to work towards common goals and those goals which needs an efficient use of feelings (George, 2000). The capacity to comprehend private feelings and emotions and other individuals ' present emotional perspective can also support a leader in his use of the correct phrases to reach supporters. In addition, after a quick identification, adverse feelings among the supporters can be delicately treated. Prati et al (2003), who indicated that IE is a good way to understand the role that emotionally smart rulers can play in guiding and directing the conduct of team members, have considered the IE elements recognized by Goleman (1995).

Emotional displacement and difficulties can lead to social pressure on teachers. Ignat and Clipa(2012) believe that these problems can readily be overcome if the educators make attempts to develop their professional and emotional skills. In this respect, emotional intelligence is an important instrument for educators to adapt their feelings and to tackle the social problems that disturb their mental equilibrium. Beilock and Ramírez (2011) also recognized the importance of studying feelings in the school setting in order to comprehend the students ' learning patterns and motivations the capacity to read and control feelings in social situations is essential for success in the interpersonal and professional field (Zeidner, Matthews and Roberts 2004). Emotional intelligence is an significant psychological factor that has a major influence on the skills and results of the employee. Earlier emotional intelligence study has found that emotional intelligence leads to certain results related to the work. However, restricted study has demonstrated that emotional intelligence has to do with beneficial results of work, especially in Pakistan's education industry. Though the Pakistani education system has improved through technological revolution and educational reform, educators are struggling to define their role as educators in the society. In addition, social requirements prevent them from balancing their feelings at job. Therefore, their emotional intelligence must be improved to enhance efficiency and achieve beneficial workrelated results. The aim of this research is to define the connection between emotional intelligence and performance of the teachers of secondary school level. In addition, how is the emotional intelligence of the educators to improve efficiency? This study is helpful to know how emotional intelligence contributes to the improvement of teachers ' performance in education institutes. It will help to design certain programs and strategies so that teachers ' emotional understanding can not only be enhanced by the task of working, but also by effectively managing their senses.

The secondary school teachers play an effective role in the educational success and personality development of students. Effective personalities of the teacher can generate brilliant students. Keeping in mind the role of secondary school teachers in the students' personality development, 
this research is aimed at investigating secondary school teacher's emotional intelligence in district Vehari.

\section{This study has following objectives:}

1. Examine the secondary school teacher's emotional intelligence level.

2. Examine and compare emotional intelligence among secondary school teachers on the basis of age, gender and teaching experience.

3. Recommend some policies to improve the EI in secondary school teachers.

\section{METHOD}

The design of the study is encompassing the research procedure and quantitative methodology. The population and sampling method were adapted as per the nature of study.

\section{Design of the study}

The research design consists of arrangement of research and the ways for guiding that research (Kerlinger, 1973). This study was based on descriptive research design; Survey method was applied to collect the data. Further the study was quantitative research in nature.

\section{Sample}

The 890 teachers of secondary school in Tehsil Mailsi of district Vehari were the study population. The list of teachers was also available on the website of the school education department Punjab (Pakistan).

The author visited the union councils (clusters). He collected data from secondary school teachers. She also got help from her friends and colleagues to collect the data. 250 filled questionnaires were returned that constitute $93.6 \%$ response rate. The data would be collected within two months from respondents.

\section{Instrument}

The researcher adopted the questionnaire for measuring the level of emotional intelligence in the teachers of secondary school. This instrument was developed by Danial Goleman in 1995 and it has consisted of 50 statements. It covers the five factors of EI i.e. self-awareness, managing oneself, managing emotions, empathy, and social skill. Each statement has five scales i.e. $4=$ Agree, 5=Strongly Agree, 3=Undecided, 2=Disagree, $1=$ Strongly Disagree. Before using this instrument, the researcher modified the language of the instrument and also translated in Urdu language. The researcher made it simple and understandable for secondary school teachers (SST/SSE).

\section{Instrument}

The researcher validated this instrument from two experts. The first was the lecturer of English department in Govt. Degree College for boys Mailsi. He told me that he had changed some words from some items because according to his opinion these words were not matched with the level of respondents. I also changed the position of some words from some items because these words were not positioned correctly according to the syntactical point of view. He modified the sentences in the sequence of sentence No. $05,13,14,16,25,26,27,31,35,36,42,44,45,46$. The second expert was an English Language teacher and he is also MA English, he also checked the sentences of this instrument and then translated the instrument into Urdu language. The researcher again checked the translation of this instrument to first expert. He changed the Translation of sentence No. 25, 35, and 46.

\section{Analysis}

Summary statistical methods such as mean, SD, independent sample t-test were used to analyze the data. Collected data were analyzed by using statistical software SPSS-21.

\section{RESULTS}

This research-based on the comparative analysis of Emotional intelligence of secondary school teachers on grounds of demographic. The prolific studies have been included in this research leading to research methodology selection. The research is primary in nature and quantitative data is collected for this research through questionnaires. The SPSS was used for the analysis and current 
chapter had highlighted results and their interpretation.

Demographic Information
The demographic analysis is encompassing the Gender, Age and Experience. The gender data shows that the males are $52.4 \%$ of data whereas females are $47.6 \%$ of entire data

\section{Gender}

Table 1 Distribution of Respondent by Gender

\begin{tabular}{|c|c|c|c|}
\hline Gender & Frequency & Percent & Cumulative Percent \\
\hline Male & 131 & 52.4 & 52.4 \\
\hline Female & 119 & 47.6 & 100.0 \\
\hline Total & 250 & 100 &
\end{tabular}

\section{Experience}

is observed in $40.8 \%$ respondents whereas more

The experience was categories into two parts less than 10 years' experience and more than ten than 10 years are representing the $59.2 \%$ of years' experience. Less than 10 years' experience respondents.

Table 1 Distribution of respondents by Experience

\begin{tabular}{|c|c|c|c|}
\hline Experience & Frequency & Percent & Cumulative Percent \\
\hline Less than 10 years & 102 & 40.8 & 40.8 \\
\hline Above 10 years & 148 & 59.2 & 100 \\
\hline Total & 250 & 100 & \\
\hline
\end{tabular}

\section{Category}

than 35 years old. $51.2 \%$ of respondents are less

The last category is from age that encompassed than 35 years old whereas $48.8 \%$ are more than 35 two divisions; less than 35 years old and more years

old

age.

Table 3 Distribution of respondents by Age

\begin{tabular}{|c|c|c|c|}
\hline Age & Frequency & Percent & $\begin{array}{c}\text { Cumulative } \\
\text { Percent }\end{array}$ \\
\hline Less than 35 Years old & 128 & 51.2 & 51.2 \\
\hline More than 35 Years old & 122 & 48.8 & 100 \\
\hline Total & 250 & 100 & \\
\hline
\end{tabular}

\section{Emotional Intelligence Level in Teachers}

The level of emotional intelligence in the teachers of high school was investigated in this study. Mean results have been computed in order to assess the teaching level of IS, including selfawareness, self-management, emotional management, compassion and social skills.

Table 4: Teachers level of EI and its sub factors

\begin{tabular}{|c|c|c|c|}
\hline Aspects & $\mathrm{N}$ & Mean & Std. Deviation \\
\hline Self-awareness & \multirow{6}{*}{250} & 2.875 & 0.939 \\
\hline managing self & & 2.916 & 0.900 \\
\hline Managing emotions & & 2.795 & 0.954 \\
\hline Empathy & & 2.992 & 0.823 \\
\hline Social skills & & 3.004 & 1.104 \\
\hline Emotional Intelligence & & 2.916 & 0.914 \\
\hline
\end{tabular}


The above table 4 shows that the level of secondary school teachers was low i.e. 2.91. It also shows that they are slightly better on empathy and social skills aspects of emotional intelligence with mean scores i.e. 3.0036 and 2.9916 respectively.

\section{Gender wise difference in the level of emotional intelligence}

The difference of mean score for males and females on self-awareness was computed through $\mathrm{t}$ test of sample. The Self-awareness was measured through 10 questions taken from the emotional intelligence questionnaire of Goleman. The Likert scale is used for the five-point scale to measure the response. The table is providing analysis of mean score difference with following hypothesis.

$\mathrm{H}_{01}$ : There is no significant difference between males and females mean scores on self-awareness.

Table 5 Gender difference in mean scores on Self-Awareness

\begin{tabular}{|c|c|c|c|c|c|c|c|}
\hline Aspect & Gender & $\mathrm{N}$ & Mean & Std. D & df & t & Sig. \\
\hline \multirow{3}{*}{$\begin{array}{c}\text { Self- } \\
\text { Awareness }\end{array}$} & Male & 131 & 2.84 & 0.94 & 248 & -0.63 & 0.44 \\
\cline { 2 - 8 } & Female & 119 & 2.91 & 0.93 & & & \\
\hline
\end{tabular}

According to the table, there is no significant mean difference for the scores of male and females in consideration of self-awareness. So, the hypothesis $\mathrm{H}_{01}$, "There is no significant difference between males and females mean scores on selfawareness" is accepted. The mean value of males is 2.84 whereas, for females' self-awareness score, it is 2.91. The difference can be stated as the reason that females are better in self-awareness as compared to males.

The difference in mean score for males and females on managing self was computed through independent sample t-test. The managing self was measured through 10 questions derived from the emotional intelligence questionnaire of Daniel. The five-point Likert scale is used to measure the response. The table is providing analysis of mean score differencing with following hypothesis.

Table 6 Gender Differences In Mean Scores on Managing Self

\begin{tabular}{|c|c|c|c|c|c|c|c|}
\hline Aspect & Gender & $\mathrm{N}$ & Mean & $\begin{array}{c}\text { Std. } \\
\mathrm{D}\end{array}$ & $\mathrm{df}$ & $\mathrm{t}$ & Sig. \\
\hline \multirow{2}{*}{ Managing Self } & Male & 131 & 2.89 & 0.91 & 248 & $\begin{array}{c}- \\
0.498\end{array}$ & 0.376 \\
\cline { 2 - 8 } & Female & 119 & 2.95 & 0.89 & & &
\end{tabular}

According to the table, there is no significant mean difference for the scores of male and
$\mathrm{H}_{02}$ : There is no significant difference between mean scores of males and females on the factor of managing self. 
between mean scores of males and females on the factor of managing self" is accepted. The mean value of males is 2.89 whereas, for females' Managing-Self score, it is 2.95. The difference of mean score for males and females on ManagingSelf was computed through independent sample-ttest. The difference can be stated as reason that females are better in managing self as compared to males
Managing Emotions was measured through 10 questions derived from the emotional intelligence questionnaire of Daniel. The Likert scale is used for the five-point scale to measure the response. The table is providing analysis of mean scores differencing with following hypothesis.

$\mathrm{H}_{03}$ : on emotions managing factors, the mean scores of males and females do not differentiate significantly.

Table 7: Gender Base Variation in Mean Values on Managing Emotions

\begin{tabular}{|c|c|c|c|c|c|c|c|}
\hline Aspect & Gender & $\mathrm{N}$ & Mean & Std. D & $\mathrm{df}$ & $\mathrm{t}$ & Sig. \\
\hline Managing & Male & 131 & 2.78 & 0.98 & 248 & -0.288 & 0.517 \\
\cline { 2 - 9 } Emotions & Female & 119 & 2.81 & 0.93 &. & & \\
\hline
\end{tabular}

According to the table, there is no significant mean difference for the scores of male and females in consideration of Managing Emotions. So the hypothesis $\mathrm{H}_{03}$, "There is no significant difference between mean scores of males and females on the factor of managing emotions" is accepted. The mean value of males is 2.78 whereas for females' managing emotions score, it is 2.81. The difference can be stated as reason that females are better in managing emotions as compared to males.

The difference of mean score for males and females on Empathy was computed through the independent sample-t-test. The Empathy was measured through 10 questions derived from the emotional intelligence questionnaire of Daniel. The Likert scale is used for the five-point scale to measure the response. The table is providing analysis of mean score differencing with following hypothesis.
$\mathrm{H}_{04}$ : There is no significant difference between mean scores of males and females on the factor of Empathy.

Table 4.8 Gender base Variation in Mean Values on Empathy

\begin{tabular}{|c|c|c|c|c|c|c|c|}
\hline Aspect & Gender & $\mathrm{N}$ & Mean & Std. D & df & t & Sig. \\
\hline \multirow{2}{*}{ Empathy } & Male & 131 & 2.97 & 0.841 & \multirow{2}{*}{248} & -0.4 & \multirow{2}{*}{0.442} \\
\cline { 2 - 5 } & Female & 119 & 3.01 & 0.81 & & & \\
\hline
\end{tabular}

According to the table, there is no significant mean difference for the scores of male and females in consideration of Empathy. So the hypothesis $\mathrm{H}_{04}$, "There is no significant difference between mean scores of males and females on the factor of Empathy" is accepted. The mean value of males is 2.97 whereas, for females' Empathy score, it is 2.01 . The difference can be stated as reason that females are better in empathy as compared to males. 
The difference between mean scores for males and females on social skills was computed through the independent sample-t-test. Social Skills was measured through 10 questions derived from the emotional intelligence questionnaire of Daniel. The Likert scale is used for the five-point scale to measure the response. The table is providing analysis of mean score differencing with following hypothesis.

$\mathrm{H}_{05}$ : There is no significant difference between mean scores of males and females on the factor of social skills.

Table 9 Gender base Variation in Mean Values on Social Skills

\begin{tabular}{|c|c|c|c|c|c|c|c|}
\hline Aspect & Gender & $\mathrm{N}$ & Mean & Std. D & df & t & Sig. \\
\hline Social & Male & 131 & 2.94 & 1.09 & 248 & -0.903 & 0.893 \\
\cline { 2 - 8 } Skills & Female & 119 & 3.07 & 1.12 & & &
\end{tabular}

According to the table, there is no significant mean difference for the scores of male and females in consideration of Social Skills. So, the hypothesis $\mathrm{H}_{05}$, "There is no significant difference between mean scores of males and females on the factor of social skills" is accepted. The mean value of males is 2.94 whereas, for females' Social Skills score, it is 3.07. The difference can be stated as reason that in case of social skills females are considered better relative to males.

The difference of mean scores for males and females on EI was computed through the independent sample-t-test. The EI was measured through 50 questions derived from the emotional intelligence questionnaire of Daniel. The Likert scale is used for the five-point scale to measure the response. The table is providing analysis of mean score differencing with following hypothesis.
$\mathrm{H}_{06}$ : There is no significant difference between mean scores of males and females on the factor of emotional intelligence.

Table 10 Gender difference in mean scores on EI

\begin{tabular}{|c|c|c|c|c|c|c|c|}
\hline Aspect & Gender & $\mathrm{N}$ & Mean & Std. D & df & t & Sig. \\
\hline Emotional & Male & 131 & 2.88 & 0.928 & 248 & -0.578 & 0.564 \\
\cline { 2 - 9 } Intelligence & Female & 119 & 2.95 & 0.9 & & &
\end{tabular}

According to the table, there is no significant mean difference for the mean scores of male and females in consideration of emotional intelligence. So, the hypothesis $\mathrm{H}_{06}$, "There is no significant difference between mean scores of males and females on the factor of emotional intelligence" is accepted. The mean score of males is 2.88 whereas for female's mean score is 2.95. The difference can be stated as reason that females are better in emotional intelligence mean score as compared to males.

Comparisons of teachers mean scores on EI teaching experience wise

The difference in mean scores for the teachers with less than 10 years' experience and more than 10 years' experience on the factor of selfawareness was computed through sample t test. 
The table is providing analysis of mean scores differencing with following hypothesis.

$\mathrm{H}_{07}$ : On emotions-managing factors, the mean values of teachers having less than and above 10 years of teaching experience does not differentiate significantly

Table 11 Comparisons of Teachers Mean Score with Less Than 10 Years and Above 10 Years of Teaching Experience on Self-Awareness

\begin{tabular}{|c|c|c|c|c|c|c|c|}
\hline & Experience & $\mathrm{N}$ & Mean & $\begin{array}{c}\text { Std. } \\
\mathrm{D}\end{array}$ & $\mathrm{df}$ & $\mathrm{t}$ & Sig. \\
\hline \multirow{2}{*}{$\begin{array}{c}\text { Self- } \\
\text { Awareness }\end{array}$} & $\begin{array}{c}\text { Less than 10 } \\
\text { years }\end{array}$ & 102 & 2.84 & 0.98 & 248 & -0.469 & 0.02 \\
\cline { 2 - 8 } & Above 10 years & 148 & 2.89 & 0.91 & & & \\
\hline
\end{tabular}

The difference in mean value was found significant for the scores of less than 10 years and above 10 years in consideration of self-awareness. So, the hypothesis $\mathrm{H}_{07}$, "There is no significant difference in mean scores of teachers having less than and above 10 years' of teaching experience analysis of mean score differencing with following hypothesis.

$\mathrm{H}_{08}$ : On self-managing factors, the mean values of teachers having less than and above 35 years' of teaching experience does not differentiate significantly. on the factor of self-awareness" is rejected. The mean value of males is 2.84 whereas, for females' self-awareness score, it is 2.90 .

The difference of mean score on managing self for teachers having experience of fewer than 10 years and above 10 years was computed through independent sample t-test. The table is providing

Table 12 Comparisons of Teachers Mean Score with Less than 10 Years and Above 10 Years of Teaching Experience on Managing Self

\begin{tabular}{|c|c|c|c|c|c|c|c|}
\hline & Experience & $\mathrm{N}$ & Mean & $\begin{array}{c}\text { Std. } \\
\mathrm{D}\end{array}$ & $\mathrm{df}$ & $\mathrm{t}$ & Sig. \\
\hline $\begin{array}{c}\text { Managing } \\
\text { Self }\end{array}$ & Less than 10 years & 102 & 2.9 & 0.94 & 248 & $\begin{array}{c}- \\
0.284\end{array}$ & 0.02 \\
\cline { 2 - 8 } & Above 10 years & 148 & 2.93 & 0.87 & & & \\
\hline
\end{tabular}

According to table, there is a significant mean difference for the scores of less than 10 years and above 10 years in consideration of Managing Self. So, the hypothesis $\mathrm{H}_{08}$, "There is no significant difference in mean scores of teachers having less than and above 10 years' of teaching experience on the factor of managing self" is accepted. The mean value of fewer than 10 years' experience is 2.90 whereas, for more than 10 years' experience Managing Self score, it is 2.93 .

The difference of mean score for managing emotions of teachers having teaching experience of fewer than 10 years and above 10 years was computed through the independent sample t-test. The table is providing analysis of mean score differencing with following hypothesis.

$\mathrm{H}_{09}$ : On emotions-managing factors, the mean values of teachers having less than and above 35 years' of teaching experience does not differentiate significantly

Table 13 Comparisons of Teachers Mean Score with Less Than 10 Years and Above 10 Years of Teaching Experience on Managing Emotions

\begin{tabular}{|l|l|l|l|l|l|l|l|}
\hline & Experience & $\mathrm{N}$ & Mean & Std. D & df & t & Sig. \\
\hline
\end{tabular}




\begin{tabular}{|c|c|c|c|c|c|c|c|} 
Managing & Less than 10 years & 102 & 2.77 & 0.99 & 248 & - & 0.175 \\
Emotions & Above 10 years & 148 & 2.81 & 0.93 & & &
\end{tabular}

According to the table, there is no significant mean difference for the scores of less than 10 emotions as compared to less experienced teachers. years and above 10 years in consideration of Managing Emotions. So, the hypothesis $\mathrm{H}_{09}$, "There is no significant difference in mean scores of teachers having less than and above 10 years' of teaching experience on the factor of managing emotions" is accepted. The mean less than 10 years' experience is 2.77 whereas, for more than 10 years' experience self-awareness score, it is 2.81. The difference can be stated as reason that experienced teachers are better in managing

The difference of mean score for Empathy of teachers having teaching experience less than 10 years and above 10 years was computed through independent sample t-test. The table is providing analysis of mean score differencing with the following hypothesis.

$\mathrm{H}_{010}$ : on empathy factors the mean value of teachers having less than and above 10 years' of teaching experience do not differentiate significantly.

Table 14 Comparisons of Teachers Mean Score with Less Than 10 Years and Above 10 Years of Teaching Experience on Empathy

\begin{tabular}{|c|c|c|c|c|c|c|c|}
\hline & Experience & $\mathrm{N}$ & Mean & $\begin{array}{c}\text { Std. } \\
\mathrm{D}\end{array}$ & $\mathrm{df}$ & $\mathrm{t}$ & Sig. \\
\hline \multirow{2}{*}{ Empathy } & Less than 10 years & 102 & 2.93 & 0.83 & 248 & $\begin{array}{c}- \\
0.941\end{array}$ & 0.746 \\
\cline { 2 - 8 } & Above 10 years & 148 & 3.03 & 0.82 & & & \\
\hline
\end{tabular}

The table shows that for values below 10 years and above 10 years, there are no important mean differences with respect to sympathy. The assumption "H010" is therefore acceptable: "There really is no mean difference in mean teacher results with less than ten years of professional experience in learning about the variable of sympathy." In contrast, over 10 years of self-awareness, the average value of less than 10 years is 2,93; The distinction is because skilled professors have stronger empathy than less skilled students. This variation in mean score is shown in figure 4.5. graphical depiction.

The median distinction in the social abilities of educators with less than ten years of professional experience and over 10 years was calculated using an autonomous sample-t-test. The table gives an assessment with the following hypothesis of mean score differentials.

H011: In the average results of educators with less than 10 years of teaching practice with the cultural variable, there is no important distinction.

Table 15 Comparison of teachers mean score with less than 10 years and above 10 years of teaching experience on social skills

\begin{tabular}{|c|c|c|c|c|c|c|c|}
\hline & Experience & $\mathrm{N}$ & Mean & Std. D & df & $\mathrm{t}$ & Sig. \\
\hline $\begin{array}{c}\text { Social } \\
\text { Skills }\end{array}$ & Less than 10 years & 102 & 2.99 & 1.18 & 248 & $\begin{array}{c}- \\
0.089\end{array}$ & 0.026 \\
\cline { 2 - 8 } & Above 10 years & 148 & 3.01 & 1.05 & & & \\
\hline
\end{tabular}

According to the table, there is a significant mean difference for the scores of less than 10 years and above 10 years in consideration of Social Skills. So, the hypothesis $\mathrm{H}_{011}$, "There is no significant

difference in mean scores of teachers having less than and above 10 years' of teaching experience on the factor of social skills" is rejected. The mean value of less than 10 years' experience is 
2.84 whereas, for more than 10 years' experience Social Skills score, it is 2.90 .

The difference of mean score for EI of teachers having teaching experience less than 10 years and above 10 years was computed through sample t- test. The table is providing analysis of mean score differencing with following hypothesis.

$\mathrm{H}_{012}$ : On emotions-managing factors, the mean values of teachers having less than and above 10 years' of teaching experience does not differentiate significantly.

Table 16 Experience wise difference of teachers mean scores on EI

\begin{tabular}{|c|c|c|c|c|c|c|c|}
\hline Aspect & Experience & $\mathrm{N}$ & Mean & Std. D & $\mathrm{df}$ & $\mathrm{t}$ & Sig. \\
\hline \multirow{2}{*}{$\begin{array}{c}\text { Emotional } \\
\text { Intelligence }\end{array}$} & $\begin{array}{c}\text { Less than 10 } \\
\text { years }\end{array}$ & 102 & 2.887 & 0.954 & 248 & -0.417 & 0.667 \\
\cline { 2 - 9 } & Above 10 years & 148 & 2.93 & 0.88 & & &
\end{tabular}

According to table, there is a significant mean difference for the scores of less than 10 years and above 10 years in consideration of EI. So, the hypothesis $\mathrm{H}_{012}$, "There is no significant difference in mean scores of teachers having less than and above 10 years' of teaching experience on emotional intelligence" is accepted. The mean value of less than 10 years' experience is 2.887 whereas, for more than 10 years' experience Social Skills score, it is 2.93 .

The difference of mean score for EI of teachers having teaching experience less than 10 years and above 10 years was computed through an independent sample $t$ test. The table is providing analysis of mean score differencing with the following hypothesis.

\section{Age wise comparisons of teachers mean scores on EI}

The difference of mean scores on self-awareness of teachers with age less than 35 years and above 35 years was computed through sample t-test. The table is providing analysis of mean score differencing with following hypothesis.

$\mathrm{H}_{013}$ : Mean scores of teachers having less than and above 35 years' of age on self-awareness does not differentiate significantly.

\section{Table.17 Comparison of Teachers Mean Score with Age Less than 35 Years and Above 35 Years on}

\section{Self-Awareness}

\begin{tabular}{|c|c|c|c|c|c|c|c|}
\hline & Age & N & Mean & Std. D & df & t & Sig. \\
\hline \multirow{2}{*}{$\begin{array}{c}\text { Self- } \\
\text { Awareness }\end{array}$} & $\begin{array}{c}\text { Less than 35 } \\
\text { Years }\end{array}$ & 128 & 2.88 & 0.95 & 248 & 0.098 & 0.251 \\
\cline { 2 - 8 } & Above 35 Years & 122 & 2.86 & 0.92 & & &
\end{tabular}

According to the table, there is no significant mean difference for the scores of Self-Awareness through mean scores of Age less than 35 years and those with Age of above 35 years. So the hypothesis $\mathrm{H}_{013}$, "There is no significant difference in mean scores of teachers having less than and above 35 years' of age on selfawareness" is accepted. The mean value of less than 35 years old is 2.88 whereas, for more than 35 years old self-awareness score, it is 2.87 . The difference can be stated as that less than 35 years age people are strong in self-awareness as compared to teachers with more than 35 years ago. The graphical representation for this difference in mean score is given in figure 4.6.The difference of mean score for managing self through mean scores of teachers with age less than 35 years and above 35 years was computed through independent sample t-test. The table is providing analysis of mean score differencing with following hypothesis.

$\mathrm{H}_{014}$ : On self-managing factors, the mean values of teachers having less than and above 35 years' of teaching experience does not differen tiate

significantly 
Table 18 Comparisons of Teachers Mean Score with Age Less Than 35 Years and Above 35 Years on Managing Self

\begin{tabular}{|c|c|c|c|c|c|c|c|}
\hline & Age & $\mathrm{N}$ & Mean & Std. D & df & t & Sig. \\
\hline \multirow{2}{*}{$\begin{array}{c}\text { Managing } \\
\text { Self }\end{array}$} & $\begin{array}{c}\text { Less than 35 } \\
\text { Years }\end{array}$ & 128 & 2.92 & 0.91 & 248 & 0.085 & 0.401 \\
\cline { 2 - 8 } & $\begin{array}{c}\text { Above 35 } \\
\text { Years }\end{array}$ & 122 & 2.91 & 0.89 & & & \\
\hline
\end{tabular}

There is no significant difference in mean values for the scores of Managing Self through mean scores of Age less than 35 years and those with Age of above 35 years. So, the hypothesis $\mathrm{H}_{014}$, "There is no significant difference in mean scores of teachers having less than and above 35 years' of age on managing self' is accepted. The mean value of less than 35 years old is 2.92 whereas, for more than 35 years old managing self-score, it is 2.91. The difference can be stated as that less than 35 years age people are strong in managing self as compared to teachers with more than 35 years age.
The graphical representation for this difference in mean scores is given in figure 4.6.

The difference of mean score for managing emotions through mean scores of teachers having age less than 35 years and above 35 years was computed through independent sample t-test. The table is providing analysis of mean score differencing with following hypothesis.

$\mathrm{H}_{015}$ : On emotions-managing factors, the mean values of teachers having less than and above 35 years' of teaching experience does not differentiate significantly

\section{Table 19 Comparisons of Teachers Mean Score with Age Less than 35 Years and Above 35 Years on Managing Emotions}

\begin{tabular}{|c|c|c|c|c|c|c|c|}
\hline & Age & $\mathrm{N}$ & Mean & $\begin{array}{c}\text { Std. } \\
\mathrm{D}\end{array}$ & $\mathrm{df}$ & $\mathrm{t}$ & Sig. \\
\hline \multirow{2}{*}{$\begin{array}{c}\text { Managing } \\
\text { Emotions }\end{array}$} & Less than 35 Years & 128 & 2.79 & 0.96 & 248 & $\begin{array}{c}- \\
0.077\end{array}$ & 0.75 \\
\cline { 2 - 8 } & Above 35 Years & 122 & 2.8 & 0.94 & & &
\end{tabular}

There is no significant difference in mean for the scores of Managing emotions through mean scores of Age less than 35 years and those with Age of above 35 years. So, hypothesis 15, "There is no significant difference in mean scores of teachers having less than and above 35 years' of age on managing emotions" is accepted. The mean value of less than 35 years old is 2.79 whereas, for more than 35 years old Managing emotions score, it is 2.80 . The difference of mean score for empathy through mean scores of teachers with age less than 35 years and above 35 years was computed through independent sample t-test. The table is providing analysis of mean score differencing with following hypothesis.

$\mathrm{H}_{016}$ : On emotions-managing factors, the mean values of teachers having less than and above 35 years' of teaching experience does not differentiate significantly.

Table 20 Comparison of Teachers Mean Score with Age Less than 35 Years and Above 35 Years on Empathy

\begin{tabular}{|c|c|c|c|c|c|c|c|}
\hline & Age & N & Mean & Std. D & df & t & Sig. \\
\hline \multirow{3}{*}{ Empathy } & $\begin{array}{c}\text { Less than 35 } \\
\text { Years }\end{array}$ & 128 & 2.97 & 0.81 & 248 & $\begin{array}{c}- \\
0.387\end{array}$ & 0.75 \\
\cline { 2 - 8 } & Above 35 Years & 122 & 3.01 & 0.83 & & & \\
\hline
\end{tabular}


There is no significant difference in mean values for the scores of empathies through mean scores of Age less than 35 years and those with Age of above 35 years. So, the hypothesis $\mathrm{H}_{016}$, "There is no significant difference in mean scores of teachers having less than and above 35 years' of age on empathy" is accepted. The mean value of less than 35 years old is 2.97 whereas for more than 35 years old empathy score, it is 3.01 . The difference can be stated as that more than 35 years age people are strong in empathy as compared to teachers with less than 35 years age.
The difference of mean score for social skills through mean scores of teachers with age less than 35 years and above 35 years was computed through independent sample t- test. The table is providing analysis of mean score differencing with following hypothesis.

$\mathrm{H}_{017}$ : On social skills, the mean scores of teachers having less than and above 35 years' of age on emotional intelligence do not differentiate significantly.

Table 21 Comparison of teachers mean score with age less than 35 years and above 35 years on social skills.

\begin{tabular}{|c|c|c|c|c|c|c|c|}
\hline & Age & $\mathrm{N}$ & Mean & Std. D & df & t & Sig. \\
\hline Social & Less than 35 Years & 128 & 3.01 & 1.13 & 248 & 0.153 & 0.422 \\
\cline { 2 - 8 } Skills & Above 35 Years & 122 & 2.99 & 1.07 & & &
\end{tabular}

There significant difference is not found in mean values for the scores of social skills through mean scores of Age less than 35 years and those with Age of above 35 years. So, the hypothesis $\mathrm{H}_{017}$, "There is no significant difference in mean scores of teachers having less than and above 35 years' of age on social skills" is accepted. The mean value of less than 35 years old is 3.01 whereas for more than 35 years old social skills score, it is 2.99. The difference can be stated as that less than 35 years age people are strong in social skills as compared to teachers with more than 35 years age.
The difference of mean score for EI through mean scores of teachers with age less than 35 years and above 35 years was computed through independent sample t- test. The table is providing analysis of mean score differencing with following hypothesis.

$\mathrm{H}_{018}$ : On emotional intelligence, the mean scores of teachers having less than and above 35 years' of age on emotional intelligence do not differentiate significantly.

Table 22 Evaluation of Teachers Mean Score with Age Less Than 35 Years and Above 35 Years On EI.

\begin{tabular}{|c|c|c|c|c|c|c|c|}
\hline & Age & $\mathrm{N}$ & Mean & Std. D & df & t & Sig. \\
\hline \multirow{2}{*}{ EI } & Less than 35 Years & 128 & 2.915 & 0.924 & 248 & -0.012 & 0.99 \\
\cline { 2 - 8 } & Above 35 Years & 122 & 2.916 & 0.906 & & & \\
\hline
\end{tabular}

According to table, there is no significant mean difference for the scores of emotional intelligences through mean scores of Age less than 35 years and those with Age of above 35 years. So, the hypothesis $\mathrm{H}_{018}$ “"There is no significant difference in mean scores of teachers having less than and above 35 years' of age on emotional intelligence" is accepted. The mean value of less than 35 years old is 2.915 whereas for more than 35 years old emotional intelligence score, it is 2.916. The difference can be stated as that above 35 years age people have stronger emotional intelligence as compared to teachers with less than 35 years age.

The difference of mean score for EI through mean scores of teachers with age less than 35 years and 
above 35 years was computed through independent sample $\mathrm{t}$ - test. The table is providing analysis of mean score differencing with following hypothesis.

\section{CONCLUSIONS}

The research uncovered that there are more than one factors affecting the EI of secondary school teachers. Five major factors of emotional intelligence encompassing the self-management, managing emotions, self-awareness, empathy, and social skills were studies. Following conclusions were drawn:

1. It was concluded that secondary school teachers have low level of emotional intelligence.

2. It was concluded that demographic variables such as age do not affect the teachers EI. Means secondary school teachers EI remains the same for the variables like age of teachers.

3. On the other hand, teaching experience affects teachers EI especially selfawareness, social skills and managing self.

4. It was also concluded that male and female secondary school teachers differ in their EI but with minimal value.

\section{REFERENCES}

[1] Ashkanasy, N. M., \& Daus, C. S. (2005). Rumors of the death of emotional intelligence in organizational behavior are vastly exaggerated. Journal of Organizational Behavior, 26(4), 441-452.

[2] Bar-On, R., \& Parker, J. D. A. (2000). BarOn emotional quotient inventory: Youth version: Multi-Health system, Incorporated Toronto, ON, Canada.

[3] Bradberry, T., \& Greaves, J. (2005). Heartless bosses. Harvard Business Review, 83(12), 24.

[4] Bradberry, T., \& Greaves, J. (2009). Emotional Intelligence 2.0: TalentSmart.

[5] Carthy, A., \& Jameson, A. (2016). An Introduction to Emotional Intelligence.

[6] Cherniss, C., Extein, M., Goleman, D., \&
Weissberg, R. P. (2006). Emotional intelligence: what does the research really indicate? Educational Psychologist, 41(4), 239-245.

[7] Chow, H. P. (2011). Procrastination among undergraduate students: effects of emotional intelligence, school life, self-evaluation, and self-efficacy. Alberta Journal of Educational Research, 57(2), 234-240.

[8] Costa, A., \& Faria, L. (2015). The impact of Emotional Intelligence on academic achievement: A longitudinal study in Portuguese secondary school. Learning and Individual Differences, 37, 38-47. doi: https://doi.org/10.1016/j.lindif.2014.11.011

[9] Curşeu, P. L., Pluut, H., Boroş, S., \& Meslec, N. (2015). The magic of collective emotional intelligence in learning groups: No guys needed for the spell! British Journal of Psychology, 106(2), 217-234.

[10] D’Souza, U., Narayana, K., Zain, A., Raju, S., Nizam, H., \& Noriah, O. (2006). Dermal exposure to the herbicide-paraquat results in genotoxic and cytotoxic damage to germ cells in the male rat. Folia morphologica, 65(1), 6-10.

[11] Edwards, R., Manstead, A., \& Macdonald, C. J. (1984). The relationship between children's sociometric status and ability to recognize facial expressions of emotion. European Journal of Social Psychology, 14(2), 235-238.

[12] Elias, M. J. (1997). Promoting social and emotional learning: Guidelines for educators: Ascd.

[13] Gento, S., González, R., \& Domínguez, M.C. The Emergency of Problems against Coexistence and Tolerance at the Educational System. Educational Improvement in Europe and other Contexts: from Theory to Practice, 85.

[14] Goleman, D. (1998). Working with Emotional Intelligence. Bantam Books, New York, N.Y.. 
[15] Goleman, D. (2001). Emotional intelligence: Issues in paradigm building. The emotionally intelligent workplace, 13, 26.

[16] Mayer, J. D., Salovey, P., \& Caruso, D. R. (2004). TARGET ARTICLES:" emotional Intelligence: theory, findings, and implications". Psychological inquiry, 15(3), 197-215.

[17] Mérida-López, S., \& Extremera, N. (2017). Emotional intelligence and teacher burnout: A systematic review. International Journal of Educational Research, 85, 121-130. doi:https://doi.org/10.1016/j.ijer.2017.07.00 6

[18] Mortiboys, A. (2013). Teaching with emotional intelligence: A step-by-step guide for higher and further education professionals: Routledge.

[19] Villalta-Gil, V., Meléndez-Pérez, I., Russell, T., Surguladze, S., Radua, J., Fusté, M., . . . Haro, J. M. (2013). Functional similarity of facial emotion processing between people with a first episode of psychosis and healthy subjects. Schizophrenia research, 149(1), 35-41.

[20] Walton, D. (2012). Introducing emotional intelligence: a practical guide: Icon Books.

[21] Yahaya, A., Ee, N. S., Bachok, J., Yahaya, N., Bon, A. T., \& Ismail, S. (2011). The relationship of dimensions of emotional intelligence and academic performance in secondary school students. Elixir Psychology, 41, 5821-5826.

[22] Yahaya, A., Ee, N. S., Bachok, J., Yahaya, N., Boon, Y., Hashim, S., \& Lee, G. M. (2012). The impact of emotional intelligence element on academic achievement. Archives Des Sciences, 65(4), 2-17.

[23] Yin, H.-b., Lee, J. C. K., Zhang, Z.-h., \& Jin, Y.-1. (2013). Exploring the relationship among teachers' emotional intelligence, emotional labor strategies and teaching satisfaction. Teaching and Teacher Education, 35, 137-145. doi:https://doi.org/10.1016/j.tate.2013.06.00 6

[24] Ying, C. Y., \& Ting, S. K. T. (2010). The relationship between emotional intelligence and effective leadership among academic heads in higher learning educational institutions. Paper presented at the International Conference on Business and Economic Research (ICBER 2010) March.

[25] Zeidner, M., Roberts, R. D., \& Matthews, G. (2002). Can emotional intelligence be schooled? A critical review. Educational psychologist, 37(4), 215-231

\section{APPENDICES}

\section{Appendix-1}

My Name is Sahrish Baqir. I am student of M Phil Education of Virtual University Lahore. I am working or Research on the topic of “Investigation of Secondary School Teacher's Emotional Intelligence In District Vehari”

So, I have required information from you about this topic. All the information collected from will be kept confidential. Thank you

\section{QUESTIONIER}

\begin{tabular}{|l|l|}
\hline Name of SST Teacher: $\quad$ Gender : & Age: $\quad$ Teaching Experience : \\
\hline $\begin{array}{l}\text { First } 10 \text { statements are about Self-awareness .11-20 are about Managing oneself. 21-30 are } \\
\text { about Managing Emotions 31-40 are about Empathy and 41-50 are about Social skill }\end{array}$ \\
\hline \hline $\begin{array}{l}\text { Please tick }(\sqrt{ }) \text { the most appropriate and suitable category in your honest opinion of each } \\
\text { Statements }\end{array}$ \\
\hline
\end{tabular}




\begin{tabular}{|c|c|c|c|c|c|c|}
\hline $4=\mathrm{A}$ & ree, $5=$ Strongly Agree, $3=$ Undecided, $2=$ Disagree, $1=$ Strongly Disa & & & & & \\
\hline S.N & STATEMENTS & 5 & 4 & 3 & 2 & 1 \\
\hline 1 & $\begin{array}{l}\text { Awareness of my own emotions is very important to me at all } \\
\text { times. }\end{array}$ & & & & & \\
\hline 2 & I know what makes me happy. & & & & & \\
\hline 3 & I realise immediately when I lose my temper. & & & & & \\
\hline 4 & I know when I am happy. & & & & & \\
\hline 5 & When I become 'emotional' I am aware of it. & & & & & \\
\hline 6 & I can tell if someone has upset or annoyed me. & & & & & \\
\hline 7 & When I feel anxious I usually can account for the reason(s). & & & & & \\
\hline 8 & I can let anger 'go' quickly so that it no longer affects me. & & & & & \\
\hline 9 & I always know when I'm being unreasonable. & & & & & \\
\hline 10 & I usually recognise when I am stressed. & & & & & \\
\hline 11 & $\begin{array}{l}\text { I am usually able to prioritise important activities at work and get } \\
\text { on with them. }\end{array}$ & & & & & \\
\hline 12 & I can always motivate myself even when I feel low. & & & & & \\
\hline 13 & Motivation has been the key to my success. & & & & & \\
\hline 14 & I am always able to motive myself to do difficult tasks. & & & & & \\
\hline 15 & I do not make excesses. & & & & & \\
\hline 16 & Delayed satisfaction is a virtue that I hold to. & & & & & \\
\hline 17 & I always meet deadlines. & & & & & \\
\hline 18 & I believe you should do the difficult things first. & & & & & \\
\hline 19 & I believe in 'Action this Day'. & & & & & \\
\hline 20 & I never waste time. & & & & & \\
\hline 21 & I rarely worry about work or life in general. & & & & & \\
\hline 22 & I can suppress my emotions when I need to & & & & & \\
\hline 23 & I can 'reframe' bad situations quickly. & & & & & \\
\hline 24 & I can consciously alter my frame of mind or mood. & & & & & \\
\hline 25 & Others can rarely tell about my mood or state my mind. & & & & & \\
\hline 26 & Difficult people do not irritate me. & & & & & \\
\hline 27 & I rarely become harsh at other people. & & & & & \\
\hline 28 & $\begin{array}{l}\text { I do not let stressful situations or people affect me once I have left } \\
\text { work. }\end{array}$ & & & & & \\
\hline 29 & Others often do not know how I am feeling about things. & & & & & \\
\hline 30 & I do not wear my 'heart on my sleeve'. & & & & & \\
\hline 31 & I can understand why my actions sometimes insult others & & & & & \\
\hline 32 & I can sometimes see things from others' point of view. & & & & & \\
\hline 33 & I am always able to see things from the other person's viewpoint. & & & & & \\
\hline 34 & I can tell if someone is not happy with me. & & & & & \\
\hline 35 & I can tell if a team of people are not working as a team. & & & & & \\
\hline 36 & I am excellent at sympathizing with someone else's problem. & & & & & \\
\hline 37 & Reasons for disagreements are always clear to me. & & & & & \\
\hline 38 & I can usually understand why people are being difficult toward & & & & & \\
\hline
\end{tabular}




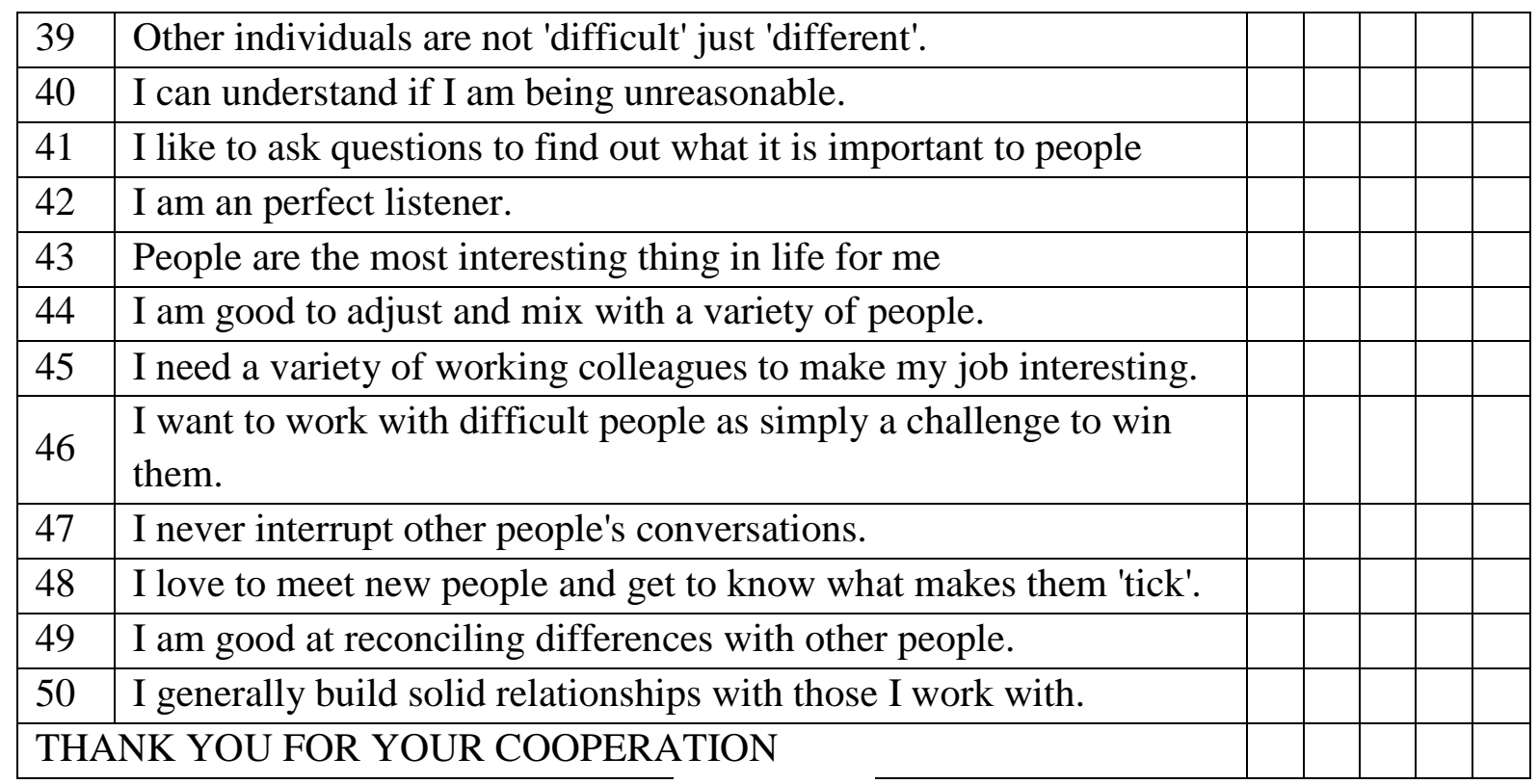

\section{Appendix-2}

Details about the Experts who helped in validation of the instrument

\begin{tabular}{|c|c|c|}
\hline Experts Names & Muhammad Yahsi Shahid & Muhammad Naeem \\
\hline Designation & $\begin{array}{c}\text { Lecturer of English department } \\
\text { in Govt. degree college for } \\
\text { boys Mailsi }\end{array}$ & $\begin{array}{c}\text { English Language teacher in } \\
\text { Govt High School Khan Pur } \\
\text { Mailsi }\end{array}$ \\
\hline Contact Number & 03007343523 & 03368639123 \\
\hline $\begin{array}{c}\text { Teaching } \\
\text { Experience }\end{array}$ & 10 Years & 6 Years \\
\hline
\end{tabular}

